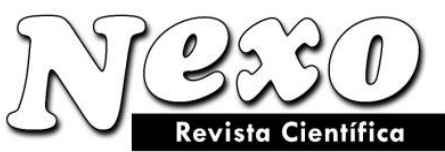

Vol. 34, No. 01, pp. 320-329/Marzo 2021

\title{
Economic mechanisms to regulate environmental protection practices in industrial and household waste management in the Russian Federation
}

\section{Mecanismos económicos para regular las prácticas de protección ambiental en la gestión de residuos industriales y domésticos en la Federación de Rusa}

\author{
Anna Geroldovna Bezdudnaya ${ }^{1 *}$, Marina Gennadievna Treyman ${ }^{1}$, Tatyana Yuryevna \\ Ksenofontova $^{2}$, Roman Valentinovich Smirnov ${ }^{1}$, Sergey Vyacheslavovich Prokopenkov ${ }^{1}$, Tatiana \\ Nikolaevna Kosheleva ${ }^{3}$ \\ ${ }^{1}$ St. Petersburg State Economic University, St. Petersburg, Russia \\ ${ }^{2}$ Emperor Alexander I St. Petersburg State Transport University, St. Petersburg, Russia \\ ${ }^{3}$ Saint Petersburg State University of Civil Aviation, St. Petersburg, Russia. \\ *annaspbru@yandex.ru
}

(recibido/received: 19-November-2020; aceptado/accepted: 18-January-2021)

\begin{abstract}
The study focuses on the aspects of environmental protection practices in the Russian Federation primarily with regard to industrial and household waste management. Waste now occupies significant areas and causes pollution of the adjacent territories and specifically underground waters that further mix with, and significantly spoil, ground waters. The study addresses the technologies of interaction and methods of economic stimulation to improve waste management going further both at the regional and national level. Almost no progress has been achieved in this direction in the Russian Federation over the past ten years the main technological mechanism adopted in major cities and other major infrastructure facilities consisted in waste removal to a landfill without any specific treatment. More recently, urban and technological development has intensified environmental problems. The paper outlines waste management practices employed in Russia and other countries and provides an efficiency assessment. The basic economic mechanisms, such as tariff regulation, environmental levy and environmental impact fees, are described and assessed in terms of their stimulating effects on waste management improvement in the Russian Federation. Aspects of waste removal under a single regional operator are discussed and a model of public-private partnership in waste management is proposed and detailed.
\end{abstract}

Keywords: Regional Operator; Tariff Regulation; Industrial and Household Waste; Waste Management Methods.

\section{RESUMEN}

El estudio se centra en los aspectos de las prácticas de protección del medio ambiente en la Federación de Rusia principalmente en lo que respecta a la gestión de residuos industriales y domésticos. Los desechos ahora ocupan áreas importantes y causan contaminación de los territorios adyacentes y específicamente de las aguas subterráneas que se mezclan y estropean significativamente las aguas subterráneas. El estudio aborda las tecnologías de interacción y los métodos de estimulación económica para mejorar la gestión de residuos yendo más allá tanto a nivel regional como nacional. Casi no se ha avanzado en esta dirección en 
la Federación de Rusia durante los últimos diez años: el principal mecanismo tecnológico adoptado en las principales ciudades y otras importantes instalaciones de infraestructura consistió en la eliminación de los desechos a un vertedero sin ningún tratamiento específico. Más recientemente, el desarrollo urbano y tecnológico ha intensificado los problemas ambientales. El documento describe las prácticas de gestión de residuos empleadas en Rusia y otros países y proporciona una evaluación de la eficiencia. Los mecanismos económicos básicos, como la regulación de tarifas, el impuesto ambiental y las tasas de impacto ambiental, se describen y evalúan en términos de sus efectos estimulantes en la mejora de la gestión de desechos en la Federación de Rusia. Se discuten los aspectos de la eliminación de residuos bajo un único operador regional y se propone y detalla un modelo de asociación público-privada en la gestión de residuos.

Palabras clave: Operador Regional; Regulación Tarifaria; Residuos industriales y domésticos; Métodos de gestión de residuos.

\section{INTRODUCTION}

One of the principal and nearly global problems today is arguably the problem of waste management, comprising not only waste removal and disposal, but also waste utilisation. Almost no progress has been achieved in this direction in the Russian Federation over the past ten years - the main technological mechanism adopted in major cities and other major infrastructure facilities consisted in waste removal to a landfill without any specific treatment. More recently, urban and technological development has intensified environmental problems. Waste now occupies significant areas and causes pollution of the adjacent territories and specifically underground waters that further mix with, and significantly spoil, ground waters. The study addresses the technologies of interaction and methods of economic stimulation to improve waste management going further both at the regional and national level.

According to the Environmental Security Strategy of the Russian Federation until 2025, previous economic operation produced more than 30,000 million tons of accumulated waste (Russian Federal Service for Supervision of Natural Resource Management, n.d.). Notably, the rate of municipal solid waste generation (MSW) has been growing. Currently, in Russia, there are more than 15 thousand industrial and household waste disposal sites occupying approximately 4 million ha in total. Moreover, this figure refers to authorised landfills. The area used for waste disposal and dumping annually increases by at least 300 thousand ha.

For Saint Petersburg, the annual MSW generation rate is approximately 8.26 million tons, which is a significant figure for the region, given that the environmental assimilating capacity of the Saint Petersburg territory is moderate and thus, natural conversion would take years, even though the territory predominantly deals with fourth and fifth-class waste.

The prevalent MSW approach in the USA, Western Europe, Canada and Asia today is automated separation processes. Sorting is meant to separate the overall waste flow into several flows and some mixed fractions to enable deep waste segregation. Specific waste residuals are dried, granulated and further used as refuse derived fuel (RDF).

As to waste dumping levels, the rate is $56 \%$ in the USA and $40 \%$ in the EU countries. Recycling processes help to reclaim up to $60 \%$ of waste as useful recycled materials.

Currently, the Russian Federation counts 243 waste recycling facilities, 50 waste sorting complexes and only 10 incineration plants (Passport of the National Programme "Ecology", 2018). Most of them were commissioned decades ago and were further modernised but still fall short of being classified as advanced high-tech complexes capable of addressing the MSW utilisation problem nationwide. 


\section{ECONOMIC MECHANISMS DIRECTLY ENGAGED IN ENVIRONMENTAL MANAGEMENT AT THE REGIONAL LEVEL}

\subsection{Tariff regulation}

Waste management and regional operators' business is regulated by the Resolution of the Government of the Russian Federation of 30.05.2016 No. 484 "On pricing in MSW management" and by the Tariff regulations in MSW management. Such legal and tariff regulations govern the industry's tariff-setting practices. The tariff committee sets the upper limit capping tariff growth; the actual rates largely depend on the territorial scheme of waste management.

According to the regulation, conditions are developing for further monopolisation of the sector and the growth of barriers preventing the emergence of new players on a competitive basis.

The methodological guidelines on calculating regulatory tariffs on MSW were approved by the Order of the Federal Antimonopoly Service of Russia of 21 November 2016 No. 1638/16 (Order of the Ministry of Economic Development of the Russian Federation No. 894, 2015).

There are no plans currently to include in the single rate the costs of MSW treatment and utilisation. That is what the environmental levy is meant to cover under extended producer (importer) responsibility (Table 1).

Table 1. Single tariffs of the regional operator for MSW management in Saint Petersburg for 2019 (Order of the Committee on Tariffs of St. Petersburg No. 30-r, 2017)

\begin{tabular}{|c|c|c|c|c|c|c|c|}
\hline \multirow{2}{*}{$\begin{array}{l}\text { Items of } \\
\text { approved tariffs }\end{array}$} & \multirow{2}{*}{$\begin{array}{l}\text { State tariff } \\
\text { authority }\end{array}$} & \multicolumn{2}{|c|}{$\begin{array}{l}\text { References of the } \\
\text { enactment on prices } \\
\text { (tariffs) }\end{array}$} & \multirow[t]{2}{*}{ Consumers } & \multirow{2}{*}{$\begin{array}{l}\text { Applicable } \\
\text { tariff rate, } \\
\text { roubles per } \\
\text { ton }\end{array}$} & \multirow{2}{*}{$\begin{array}{l}\text { Effective } \\
\text { period }\end{array}$} & \multirow{2}{*}{$\begin{array}{l}\text { Official } \\
\text { publication } \\
\text { source of the } \\
\text { enactment on } \\
\text { prices (tariffs) }\end{array}$} \\
\hline & & Date & $\begin{array}{l}\text { Ref. } \\
\text { number }\end{array}$ & & & & \\
\hline \multirow{4}{*}{$\begin{array}{l}\text { Threshold single } \\
\text { tariff rates of the } \\
\text { regional operator } \\
\text { for MSW } \\
\text { management in } \\
\text { Saint Petersburg } \\
\text { (within the } \\
\text { territorial scope } \\
\text { of regional } \\
\text { operator No. 1) }\end{array}$} & \multirow{4}{*}{$\begin{array}{l}\text { Saint } \\
\text { Petersburg } \\
\text { Committee } \\
\text { on Tariffs }\end{array}$} & \multirow{4}{*}{28.09 .18} & \multirow{4}{*}{ No. 118-r } & $\begin{array}{l}\text { Consumers except } \\
\text { households (VAT } \\
\text { not included) }\end{array}$ & $3,671.58$ & \multirow{2}{*}{$\begin{array}{l}\text { from } \\
01.01 .19 \\
\text { to } \\
30.06 .19\end{array}$} & \multirow{4}{*}{$\begin{array}{l}\text { Bulletin of the } \\
\text { Saint } \\
\text { Petersburg } \\
\text { Committee on } \\
\text { Tariffs }\end{array}$} \\
\hline & & & & $\begin{array}{l}\text { Households (VAT } \\
\text { included) }\end{array}$ & $4,405.90$ & & \\
\hline & & & & $\begin{array}{l}\text { Consumers except } \\
\text { households (VAT } \\
\text { not included) }\end{array}$ & $3,671.58$ & \multirow{2}{*}{$\begin{array}{l}\text { from } \\
01.07 .19 \\
\text { to } \\
31.12 .19\end{array}$} & \\
\hline & & & & $\begin{array}{l}\text { Households (VAT } \\
\text { included) }\end{array}$ & $4,405.90$ & & \\
\hline
\end{tabular}

\subsection{Environmental levy}

Extended producer responsibility means that producers and importers assume responsibility for the disposal of waste from their goods, including packaging, when they lose consumer value.

Such waste disposal includes the following possibilities:

- recycling and reuse;

- recovery for further use in the production cycle following proper preparations (regeneration); 
- extraction of usable components for repeat use (recuperation).

Order of the Government of the Russian Federation of 24.09.2015 No. 1886-r provides a list of end products, including packaging, subject to utilisation after the loss of consumer value.

Some of the aggregate groups are as follows:

- Corrugated paper and fiberboard, paper and fiberboard packaging;

- Household and sanitary and hygiene products, toiletry;

- Other paper and fiberboard products;

- Tires, cases and rubber tubes; retreading;

- Other rubber products;

- Plastic packaging items;

- Plastic construction products;

- Shaped and finished glass sheets;

- Hollow glassware;

- Computers and periphery, etc (Alekseev, 2014, p. 17).

Producers determine utilisation requirements for their products based on product codes under the Russian Classification of Products by Economic Activity Types OK 034-2014 (CPA 2008). Importers should refer to codes under Foreign Economic Activity Commodity Nomenclature of the Eurasian Economic Union (FEACN of the EAEU).

Producers and importers are required to annually file reports to the Federal Service for Supervision of Natural Resource Management on compliance with product waste utilisation ratios. A system of reliefs is available to consumers of recycled materials, including a decreasing coefficient and a system of product utilisation.

Federal budget revenues from environmental levies are meant for use in the following directions:

- construction and reconstruction of technological complexes for waste treatment;

- development of technological equipment for waste utilisation and programmes to deploy it;

- co-funding of regional industrial and household waste management programmes.

However, the mechanism of funding lacks transparency and there are no established practices of cooperation with enterprises handling waste utilisation in regions. Environmental levy rates are laid out in Table 2. 
Table 2. Environmental levy rates for 2019 (main types of waste)

\begin{tabular}{|l|l|}
\hline Product group & Official rate (roubles per ton) \\
\hline Paper and fiberboard (corrugated fiberboard packaging) & 2,378 \\
\hline $\begin{array}{l}\text { Paper bags, household sanitary and hygiene items, paper } \\
\text { stationery }\end{array}$ & 2,378 \\
\hline Plastic packaging (bags, bottles, boxes up to 2 1) & 3,844 \\
\hline Plastic packaging (bags, bottles, boxes above 2 1) & 3,844 \\
\hline Hollow glassware (bottles, jars, kitchenware, stoppers, lids) & 2,564 \\
\hline
\end{tabular}

As highlighted in Table 2, no development is possible in the sector without an established market of recycled materials. It means there need to be economic preconditions in place (Federal Law of the Russian Federation No. 89-FZ, 1998).

When the price of dumping is at its lowest, there are no economic incentives to develop waste recycling. The same is true for buying recycled materials where relatively cheap and affordable natural resources are available.

Federal Law No. 7-FZ of 10.01.2002 "On environmental protection", and specifically Article 24, puts forth a requirement to set the ratios of industrial and household consumption waste production and maximum limits on the disposal thereof (Federal Law of the Russian Federation No. 7-FZ, 2002). The evidence collected for mapping out the territorial schemes of waste management suggests that in many agglomerations, the established limits of MSW disposal are exceeded, which results in extended cycles of MSW delivery to the nearby territories and consequently increased single tariffs of MSW treatment.

\subsection{Environmental impact fees for regional operators}

Pursuant to the latest amendments to Federal Law No. 7-FZ of 10.01.2002 "On environmental protection", regional operators and MSW management operators are obliged to pay to the federal budget for environmental impact as a result of MSW disposal.

Starting January 1, 2019, waste removal charges include the component of "environmental impact fees". The breakdown of this charge is as follows:

- approximately $5 \%$ will be assigned to the federal budget;

- $45 \%$ will be directed to the regional budget;

- 50\% will be assigned to the municipality where the disposal site is located (Federal Law of the Russian Federation No. 7-FZ, 2002).

Other agents in the market include regional operators obliged to sign agreements for MSW management services with MSW holders if waste generation and accumulation occur in their territorial domain.

\section{SINGLE REGIONAL OPERATOR AND WASTE MANAGEMENT OPERATIONS IN THE RUSSIAN FEDERATION}

Acting separately in the market are MSW management operators arranging waste transfer, processing, utilisation, neutralisation and dumping (Figure 1). 


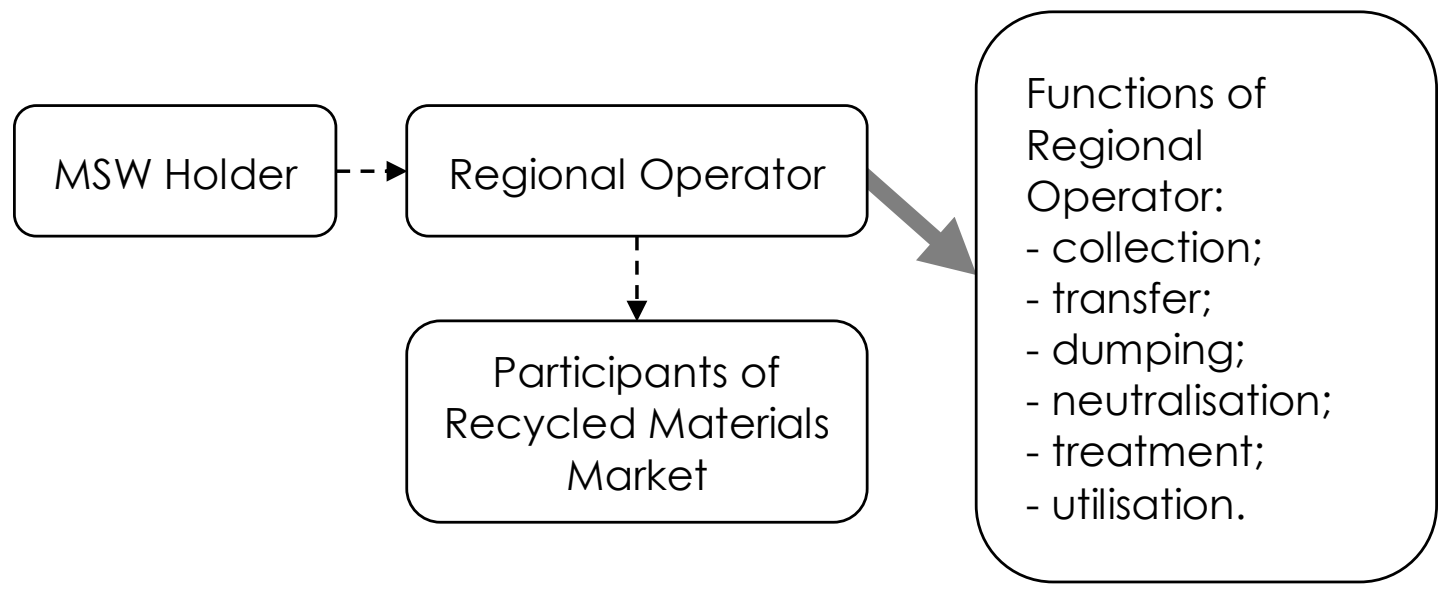

Figure 1. Model of municipal-private partnership in the industrial and household waste management industry

For example, on the territory of the Leningrad Region there are 15 regional waste handling operators. The table shows 4 main stages of technological treatment of various types of waste. According to the table, the stages that are performed are marked with a plus $(+)$, those that are not performed are marked with a minus (-). According to Table 3, for the most part, waste in the Leningrad region goes to dumping sites; some landfills apply additional waste processing methods.

Table 3. Specifics of technological treatment of various types of waste in the Leningrad region (Naumova, 2015, p. 104; Administration of the Leningrad region, n.d.).

\begin{tabular}{|l|l|l|l|l|l|}
\hline Item & Description & Treatment & Neutralisation & Utilisation & Dumping \\
\hline 1 & $\begin{array}{l}\text { Zavod MPBO-2, } \\
\text { St. Petersburg State Unitary } \\
\text { Enterprise }\end{array}$ & + & + & - & - \\
\hline 2 & Ekolend, OOO & + & - & - & - \\
\hline 3 & TEK, OOO & + & - & - & - \\
\hline 4 & AVTO-BERKUT, OOO & - & - & - & + \\
\hline 5 & Lel-EKO, OOO & + & - & - & + \\
\hline 6 & $\begin{array}{l}\text { UK po obrashcheniyu s } \\
\text { otkhodami v Leningradskoi } \\
\text { oblasti, AO }\end{array}$ & + & - & - & + \\
\hline 7 & Blagoustroistvo, OOO & - & & & \\
\hline 8 & Profspetstrans, OOO & + & - & - & + \\
\hline 9 & Promotkhody, ZAO & - & - & - & + \\
\hline 10 & Poligon TBO, OOO & - & - & - & + \\
\hline 11 & RASEM, OOO & - & - & - & + \\
\hline 12 & Novyi Svet-Eko, OOO & - & - & - & + \\
\hline 13 & $\begin{array}{l}\text { Landfill of Chistyi gorod, } \\
\text { OAO }\end{array}$ & - & - & - & + \\
\hline 14 & Eko-PLANT, OOO & - & - & - & + \\
\hline 15 & LOEK, OOO & - & - & - & + \\
\hline
\end{tabular}

Another integral link in the waste management industry are arguably businesses using the resulting recycled resources in production. Unless all these links are in place, there is no economic sense in MSW sorting and treatment (Ksenofontova, 2012, p. 151). 
Other agents engaged in this business necessarily include concessioners (private investors) and organisations providing funding for waste management operations. All operations in the waste management industry are governed by statutory regulations, including the approaches to establishing the uniform ratios of waste accumulation.

An important indicator of environmental performance is the accumulation ratio. A comparison of global and local figures indicates the ratio is higher abroad, at $500 \mathrm{~kg}$ per individual per year. Meanwhile, in Russia, the respective figure equals $300-350 \mathrm{~kg}$ per year.

Saint Petersburg waste accumulation ratios set in 2018 are laid out in Table 4.

These ratios are used to project capacities of landfills in the federal subjects of the Russian Federation. This results in a shortage of landfill and waste storage facilities in agglomerations.

Table 4. Environmental levy rates for 2019 (main types of waste)

\begin{tabular}{|l|l|l|}
\hline Category of operation & Unit & $\begin{array}{l}\text { MSW accumulation ratio per } \\
\text { year (kg) }\end{array}$ \\
\hline Organisations and institutions & per individual & 234.8 \\
\hline Groceries & $1 \mathrm{~m}^{2}$ & 269.9 \\
\hline Non-food and household retailers & $1 \mathrm{~m}^{2}$ & 231.9 \\
\hline Pre-school education institutions & per individual & 250.5 \\
\hline General education institutions & per individual & 92.4 \\
\hline Public catering organisations & $1 \mathrm{~m}^{2}$ & 527.3 \\
\hline Apartment blocks & per individual & 381.7 \\
\hline Stand-alone houses & Single property & 696.9 \\
\hline
\end{tabular}

The same ratios are used to calculate vehicle requirements to remove waste; vehicle availability is also a significant problem.

When these ratios are brought to actual figures, the significant shortage will be revealed both in terms of disposal sites and treatment facilities.

Another aspect of the existing rationing system is the use of actual rates of waste production without engaging the regulatory function or building incentives for resource-saving.

\section{DEVELOPMENT OF MECHANISMS OF PUBLIC-PRIVATE PARTNERSHIP IN INDUSTRIAL AND HOUSEHOLD WASTE MANAGEMENT}

Projects of public-private partnership should provide financial and socioeconomic effects. Local authorities conduct comparative analyses of submitted project solutions.

Projects prioritised as the most attractive are those which:

- reduce to a minimum the level of the net present value of budget spending from the budget system of the Russian Federation;

- reduce to minimum project risks and cut total commitments of the municipal government.

Accordingly, the most attractive projects are those, which can be fully implemented at the cost of the private party. 
In such case, particular focus should be placed on ensuring investment attractiveness of the waste management industry. Projects concerned with design and construction of waste treatment and neutralisation facilities, including complexes for sorting, segregating utilisable fractions and decontaminating hazardous waste, run major risks and uncertainties in terms of business inputs.

The primary proposition in the concept should be that recycled materials are to be addressed as commodities to be used to a maximum level in closed operational cycles of an enterprise.

It is specifically the stimulated development and advance of the recyclables market that is integral in the creation of an economically attractive waste management sector.

The principal scheme of interaction between the subjects of this business is shown in Figure 2.

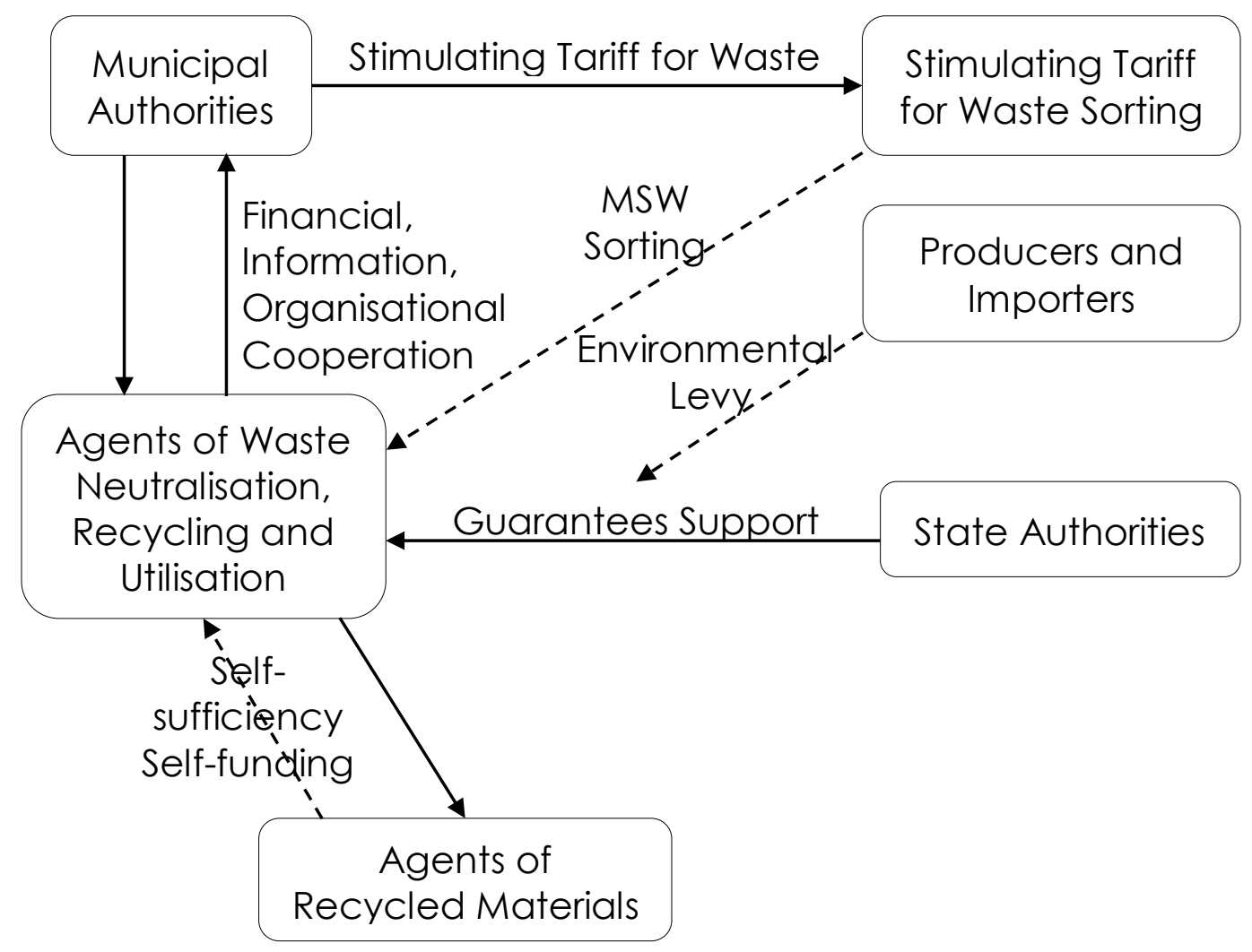

Figure 2. Model of municipal-private partnership in the industrial and household waste management industry

Arguably, providing support to the participants of the recycled materials market, i. e., the buyers of recycled materials, can contribute to full financial viability and, further, profitability of investment projects engaged with the construction of MSW neutralisation, treatment and utilisation.

An established and secure market for recycled materials in place would provide the potential for attracting investors, particularly, on conditions of complete self-funding of investment operations.

It will make it possible to create projects without the use of budget funds, which could solely serve as a guarantee mechanism. 
Currently, the source of funding for the development of this sector is the item Environmental levy. However, the distribution of amounts generated from this levy among the regions is disproportionate. These revenues are used for one-off projects having no systemic impact over economic development in most regions with regard to waste management.

Revenues from this levy can be also channelled to dedicated support funds across the Russian Federation and serve not as much for the construction, reconstruction or modernisation of enterprises, but for providing support to enterprises engaging recycled materials (e. g., providing additional production equipment) and subsidising the decreased rates of the single tariffs (for waste collection, transfer and dumping) for sorting MSW at the early stages of use.

Creation of an enterprise for MSW treatment is only viable given proper infrastructure in place. Additional profits can be earned by preliminary sorting of MSW.

Municipal authorities are responsible for ensuring project support over time, guaranteeing the availability of financial resources in adverse market circumstances and in case of additional funding requirements arise and creating conditions for information cooperation.

Municipal authorities should ensure local regional awareness of:

- the need to arrange selective waste collection;

- the system of incentives (e. g., lowered coefficients on tariffs for sorting MSW);

- projects implemented in the region and their security profile and objectives.

Other crucial directions include:

- providing regional enterprises with information on the availability of recycled materials and purchasing prices;

- ensuring transparency of information on the quantity, structure and characteristics of waste, the system of transfer to treatment facilities, etc.

Municipal authorities are responsible for creating the conditions for maintaining a stable resource flow and development of the markets, i. e. flows after treatment.

In this sphere, the most fundamental managerial approaches need to be developed, including innovative waste treatment solutions and improved sorting methods, and stable functioning of waste treatment technologies should be ensured.

\section{CONCLUSIONS}

Innovative solutions can potentially ensure demand for recycled material resources. Currently, there are no set industrial requirements in the Russian Federation regarding the consumption of recycled materials, no technological solutions in this context nor significant engineering research into it.

Currently, the market for recycled materials is underdeveloped, and for that reason, a majority of implemented projects are waste incineration projects, which address environmental problems but provide no additional benefits for businesses. Incineration provides no opportunity to reclaim useful fractions in 
full. Therefore, introducing the mechanisms of public-private partnerships would enable an inflow of additional investment and would help to develop the methods of MSW treatment in a more efficient way.

\section{REFERENCES}

Russian Federal Service for Supervision of Natural Resource Management. (n.d). Retrieved from: http://rpn.gov.ru/

Naumova, A.A. (2015). Analiz podkhodov po utilizatsii bytovykh vtorichnykh materialnykh resursov [Analysis of approaches to utilisation of recycled materials]. Aktualnye problemy gumanitarnykh i estestvennykh nauk [Current problems of humanities and natural sciences], 6(2), 101-105.

Administration of the Leningrad region. (n.d.). Retrieved from: http://lenobl.ru/

Order of the Ministry of Economic Development of the Russian Federation No. 894. (November 30, 2015). "On approval of the efficiency assessment method of public-private partnership, municipal-private partnership projects and determination of their comparative advantage". Retrieved from: http://publication.pravo.gov.ru/Document/View/0001201512310052

Order of the Committee on Tariffs of St. Petersburg No. 30-r. (April 14, 2017). Retrieved from: https://www.gov.spb.ru/gov/otrasl/energ_kom/documents/npa/7118/

Alekseev, A.A. (2014). Pererabotka vtorichnykh materialnykh resursov - innovatsionnyi segment promyshlennosti [Recycling as innovative industrial segment]. Izvestiya Sankt-Peterburgskogo gosudarstvennogo ekonomicheskogo universiteta [Bulletin of the St. Petersburg State University of Economics], 3, 17-23.

Ksenofontova, T.Iu. (2012). Intellektualnyi kapital proizvodstvennogo predpriyatiya kak kriterii otsenki ego konkurentosposobnosti [Intellectual capital of a production enterprise as competitiveness criteria]. Vestnik INZHEKONa [Bulletin of INZHEKON]. Series: Economics, 3, 151-159.

Federal Law of the Russian Federation No. 89-FZ. (June 24, 1998). "On industrial and household waste". Retrieved from: http://www.kremlin.ru/acts/bank/12555

Federal Law of the Russian Federation No. 7-FZ. (January 10, 2002). "On environmental protection". Retrieved from: http://kremlin.ru/acts/bank/17718

Passport of the National Programme "Ecology". (September 24, 2018). Adopted by the presidium of the Russian Federation Presidential Council for strategic development and national projects, No. 12. Retrieved from: http://static.government.ru/media/files/pgU5Ccz2iVew3Aoel5vDGSBjbDn4t7FI.pdf 